\title{
Stimuli-Responsive Cationic Hydrogels in Drug Delivery Applications
}

\author{
G. Roshan Deen ${ }^{1, *}$ and Xian Jun Loh ${ }^{2}$ \\ 1 Soft Materials Laboratory, Natural Sciences and Science Education AG, National Institute of Education, \\ Nanyang Technological University, 1-Nanyang Walk, Singapore 637616, Singapore \\ 2 Institute of Materials Research and Engineering, 2-Fusionopolis Way, Singapore 138634, Singapore; \\ lohxj@imre.a-star.edu.sg \\ * Correspondence: roshan.gulam@nie.edu.sg; Tel.: +65-6790-3816
}

Received: 13 December 2017; Accepted: 30 January 2018; Published: 1 February 2018

\begin{abstract}
Stimuli-responsive, smart, intelligent, or environmentally sensitive polymers respond to changes in external stimuli such as $\mathrm{pH}$, temperature, ionic strength, surfactants, pressure, light, biomolecules, and magnetic field. These materials are developed in various network architectures such as block copolymers, crosslinked hydrogels, nanogels, inter-penetrating networks, and dendrimers. Stimuli-responsive cationic polymers and hydrogels are an interesting class of "smart" materials that respond reversibly to changes in external $\mathrm{pH}$. These materials have the ability to swell extensively in solutions of acidic $\mathrm{pH}$ and de-swell or shrink in solutions of alkaline $\mathrm{pH}$. This reversible swelling-shrinking property brought about by changes in external $\mathrm{pH}$ conditions makes these materials useful in a wide range of applications such as drug delivery systems and chemical sensors. This article focuses mainly on the properties of these interesting materials and their applications in drug delivery systems.
\end{abstract}

Keywords: cationic polymers; hydrogels; stimuli-responsive; heterocyclic; swelling of gels; drug-delivery systems

\section{Introduction}

Polymers that respond to changes in external stimuli are called stimuli-responsive, smart, intelligent, or environmentally sensitive polymers. These materials can be in the form of linear polymers (homo polymers, copolymers), crosslinked polymers in the form of hydrogels, inter-penetrating networks, and micro/nanogels. The external stimuli can be either physical, chemical, or biochemical in nature, in the form of $\mathrm{pH}$, temperature, salts, surfactants, light, pressure, biomolecules, and magnetic field [1-5]. The responses to these external stimuli occur in the form of conformational, optical, and chemical changes. The different types of stimuli that bring about these changes are illustrated in Figure 1. These changes are accompanied by variation in the physical properties of the polymer. On a macroscopic level, the changes are apparent as phase separation from aqueous solution (for linear polymers and linear copolymers) or volume changes (for crosslinked systems) [5-10]. The temperature at which such transitions occur is termed the lower critical solution temperature (LCST) or volume-phase transition temperature (VPT) [11]. This article focuses specifically on cationic polymers in the form of hydrogels and their applications in drug delivery applications. 


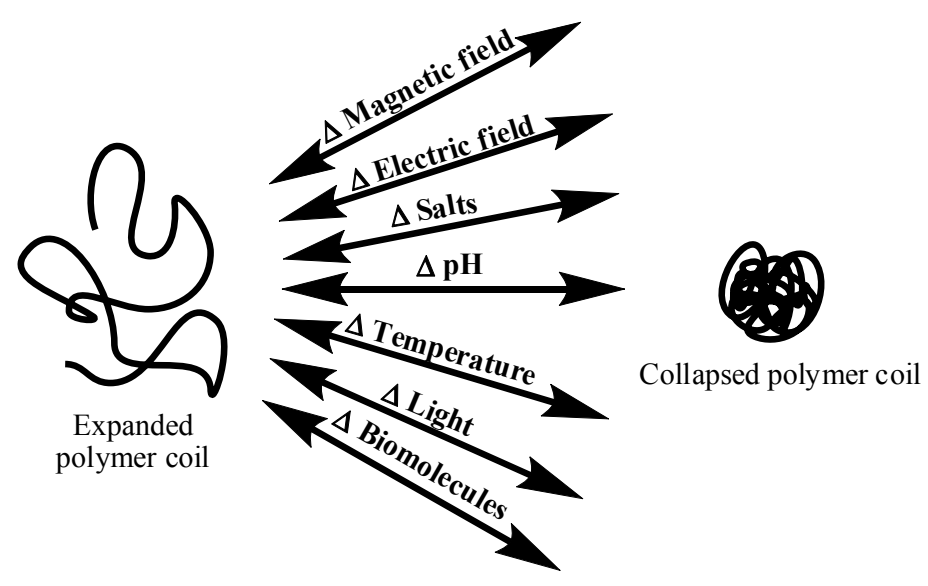

Figure 1. Stimuli-response behavior of polymer chains in response to various external stimuli.

Hydrogels that contain polycations and are sensitive to external $\mathrm{pH}$ changes are called cationic hydrogels. The tertiary amine functional groups present in these hydrogels are protonated below their dissociation constant $\left(p K_{\mathrm{a}}\right)$ in acidic solutions, causing the hydrogels to swell extensively. This pH-dependent swelling is shown in Figure 2 [12-16]. A few examples of cationic hydrogels are based on poly( $N, N$-dialkylaminoethyl methacrylate), poly(lysine), chitosan, poly(amido-amine), etc. The chemical structures of some $\mathrm{pH}$-sensitive synthetic cationic polymers such as poly(dimethylaminoethyl methacrylate) (PDMAEMA), poly(diethylaminoethyl methacrylate) (PDEAEMA), poly(ethyl pyrrolidine methacrylate) (PEP), and poly(ethyl piperazine acrylate) (PAcrNEP) are shown in Figure 3. Hydrogels based on these chemical moieties swell extensively in solutions with a low $\mathrm{pH}$ due to the protonation of tertiary amine functional groups, which leads to the formation of fixed electric charges on the macromolecule. The degree of swelling of cationic hydrogel depends largely on the $p K_{\mathrm{a}}$ of the ionic group, concentration of the monomer, crosslinking ratio, $\mathrm{pH}$, and ionic strength of the external medium $[17,18]$.

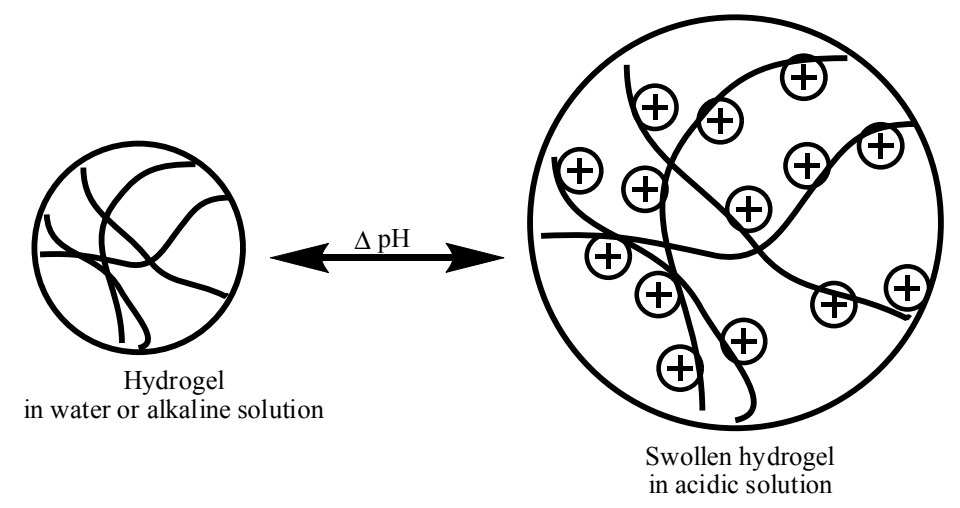

Figure 2. Swelling of hydrogel in acidic solution due to the formation of fixed charges on the polymer network. 


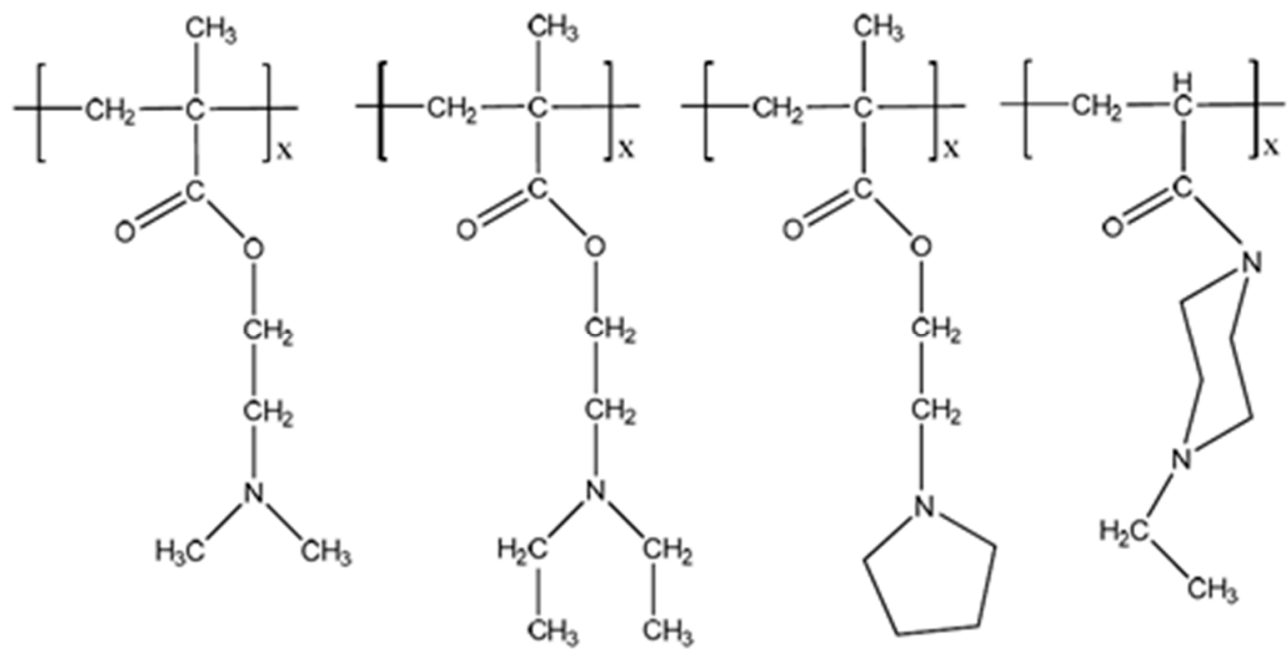

Figure 3. Chemical structure of cationic polymers (1) poly(dimethylaminoethyl methacrylate) (PDMAEMA); (2) poly(diethylaminoethyl methacrylate) (PDEAEMA); (3) poly(ethyl pyrrolidine methacrylate) (PEP); (4) poly(ethyl piperazine acrylate) (PAcrNEP).

In recent years, cationic hydrogels that exhibit response to more than one stimuli, such as $\mathrm{pH}$ and temperature, have attracted much research attention in biomedical applications. These polymeric materials are obtained from new synthetic monomers containing tertiary amine functional groups [17-19]. This has been achieved by the following chemical synthesis approaches: (i) the copolymerization of monomers with desired functional groups [20-25], (ii) the copolymerization or combination of thermo-sensitive polymers with polyelectrolytes [26,27], (iii) the formation of inter-penetrating networks through combination of various stimuli-sensitive polymers [28,29], and (iv) the chemical synthesis and polymerization of new functional monomers [30,31].

Cationic polymers and hydrogels are an interesting class due to their $\mathrm{pH}$ sensitivity and due to their ability to complex with other systems with anionic character [32]. As a result of these characteristics, cationic polymers and hydrogels have been widely evaluated as alternative vectors to viruses in gene delivery and therapy $[33,34]$. The nature of cationic groups and their influence on transfection efficiency and biodegradability has been studied for cationic polymers based on poly(phosphoramides) [33-35].

\section{Swelling Behavior of Cationic Hydrogels}

The most favorable property of hydrogels is their ability to swell when placed in contact with a thermodynamically compatible solvent. Solvent molecules penetrate the glassy surface of the hydrogel and slowly diffuse into the network. The physicochemical models that describe the swelling of cationic hydrogels are usually based on the free energy change that takes place due to the following factors [34-37]: (i) the osmotic pressure of counterions within the gel (Donnan theory); (ii) the mixing of polymer with solvent (Flory-Huggins theory); (iii) the stretching of polymer chains (Flory-Rehner theory).

The total free energy change of a hydrogel at equilibrium swelling is given by the Gibbs free energy equation [38]:

$$
\Delta G_{\text {Total }}=\Delta G_{\text {Mixing }}+\Delta G_{\text {Elastic }}
$$

where $\Delta G_{\text {Total }}$ is the change of total free energy in hydrogel, $\Delta G_{\text {mixing }}$ is the free energy due to the mixing of solvent molecules with polymer chains, and $\Delta G_{\text {elastic }}$ is the free energy of the elastic retractive force of the hydrogel.

In the case of ionic hydrogels, the theoretical treatment of equilibrium swelling is more complicated, as swelling depends to a large extent on the degree of ionization of functional groups, as 
well as the ionic strength of the external solution. Therefore, the ionic groups impart an additional free energy change $\left(\Delta G_{\text {ionic }}\right)$ to the total free energy of the hydrogel. The total free energy change of the ionic hydrogel is given as:

$$
\Delta G_{\text {Total }}=\Delta G_{\text {Mixing }}+\Delta G_{\text {Elastic }}+\Delta G_{\text {ionic }}
$$

The ionic gel is subjected to a swelling pressure, $\pi$, which comprises three components similar to the total free energy:

$$
\pi_{\text {Total }}=\pi_{\text {mixing }}+\pi_{\text {elastic }}+\pi_{\text {ionic }}
$$

where $\pi_{m i x}$ is the osmotic pressure due to the mixing of solvent with polymer, $\pi_{\text {elastic }}$ is the osmotic pressure due to the elastic force of the gel, and $\pi_{\text {ionic }}$ is the osmotic pressure due to the ionic contribution. The equilibrium swelling is obtained when $\pi_{\text {Total }}$ is set equal to zero.

The osmotic pressure due to mixing, $\pi_{\text {mix }}$, is given by the Flory-Huggins theory [36]:

$$
\pi_{\text {mixing }}=-\frac{R T}{V_{1}}\left[\ln (1-v)+v+\chi v^{2}\right]
$$

where $v$ is the polymer volume fraction, $V_{1}$ is the molar volume of solvent, and $\chi$ is the Flory-Huggins interaction parameter.

The osmotic pressure due to elastic or configurational contribution $\left(\pi_{\text {elastic }}\right)$ is obtained from $\Delta G_{\text {elastic }}$, during the swelling of hydrogels. Under isotropic swelling, this is obtained by differentiating $\Delta G_{\text {elastic }}$ with respect to volume and expanding the inverse Langevin function in a power series, as given by the following expression [39]:

$$
\begin{gathered}
\pi_{\text {elastic }}=-v_{0} R T\left[\left(\frac{v}{v_{0}}\right)^{1 / 3}-\frac{1}{2}\left(\frac{v}{v_{0}}\right)\right]-v_{0} R T \\
{\left[\frac{3}{5}\left(\frac{v_{0}}{v}\right)^{1 / 3} \times \frac{1}{n}=\frac{99}{175}\left(\frac{v_{0}}{v}\right) \frac{1}{n^{2}}+\frac{513}{875}\left(\frac{v_{0}}{v}\right)^{5 / 3} \frac{1}{n^{3}}+\ldots\right]}
\end{gathered}
$$

where $v_{0}=v_{0} v_{\mathrm{d}}$ is the concentration of polymer chains when the gel is formed.

The ionic contribution to the osmotic pressure $\left(\pi_{i o n}\right)$ arises due to the difference between the osmotic pressure of mobile ions in the gel and in the external solution. This is given by [39]:

$$
\pi_{\text {ionic }}=R T\left[\Phi \sum_{i} \overline{C_{i}}-\phi \sum_{i} C_{i}\right]
$$

where $C_{\mathrm{i}}$ and $\overline{C_{i}}$ are the concentrations of mobile ions in the external solution and gel; $\phi$ and $\Phi$ are the corresponding osmotic coefficients, respectively. This implies that charged or ionizable groups present in gels play an important role in swelling behavior. The following equation describes the swelling of cationic hydrogels in the presence of a solvent and their abovementioned dependencies [37-39]. Using this expression, the network structure of cationic gels can be characterized.

$$
\begin{gathered}
\frac{V_{1}}{4 I}\left(\frac{v_{2, s}^{2}}{\bar{v}}\right)\left(\frac{K_{\mathrm{b}}}{10^{\mathrm{PH}-14}-K_{\mathrm{a}}}\right)^{2}=\left[\ln \left(1-v_{2, s}\right)+v_{2, s}+\chi v_{2, s}^{2}\right]+ \\
\left(\frac{V_{1}}{v \bar{M}_{c}}\right) \times\left(1-\frac{2 \bar{M}_{c}}{\bar{M}_{n}}\right) v_{2, r}\left\lfloor\left(\frac{v_{2, s}}{v_{2, r}}\right)^{1 / 3}-\left(\frac{v_{2, s}}{2 v_{2, r}}\right)\right\rfloor
\end{gathered}
$$

where $I$ is the ionic strength, $K_{\mathrm{a}}$ is the acid dissociation constant, $K_{\mathrm{b}}$ is the base dissociation constant, $M_{c}$ is the molecular weight between crosslinks, $M_{n}$ is the molecular weight of polymer chains without crosslinks, $V_{1}$ is the molar volume of water, $v_{2}, r$ is the volume fraction of the polymer in the relaxed state, $v_{2}, s$ is the volume fraction of the polymer in the swollen state, and $\chi$ is the polymer-solvent interaction parameter. 


\section{Applications of Cationic Hydrogels}

Cationic hydrogels have found several applications in the biomedical industry such as targeted drug delivery, gene delivery, and tissue engineering.

\subsection{Drug Delivery Systems}

The process of administering a pharmaceutical compound to a targeted organ to achieve a therapeutic effect in humans or animals is the principle of targeted drug delivery systems. Due to the variation of $\mathrm{pH}$ (between 2 in the stomach to neutral in the small intestine) along the gastrointestinal tract (GI), it is still the most sought after route for drug delivery [40]. It is also the most complex route and therefore various approaches are required for the effective delivery of drugs. A few of the obstacles that need to be overcome for efficient drug delivery include the degradation of drugs and the carrier (gels) by enzymes, rapid removal of the carrier from the body, non-specific toxicity of carrier, etc. In this regard, stimuli-responsive systems allow the advantage of delivering the right amount of drug at the right time in response to changes in external stimuli. Cationic gels, for example, can expand as a result of the ionization of functional moieties present along the macromolecular chain in an acidic condition, thus promoting drug diffusion and release in the stomach [40].

Several cationic hydrogels based on heterocyclic compounds, such as morpholine and pyrolidinone, have been widely studied by San Román and co-workers $[27,28,30]$. The same group also developed polymers in which an anti-aggregant drug called Triflusal was covalently attached (polymeric prodrugs) [41]. A novel poly(vinylpyrrolidone-co-dimethylmaleic anhydride) (PVD) carried drug was synthesized by Kamada and co-workers [42]. The incorporated pH-sensitive vinylpyrrolidone cationic monomers allowed the conjugation of the drug Adriamycin at $\mathrm{pH} 8.5$, with gradual release at $\mathrm{pH} 6$ to 7 . The PVD-Adriamycin conjugate has shown anti-tumor activity against Sarcoma-180 solid tumor in mice.

An injectable hydrogel based on vinylpyrrolidine, NIPAM, and acrylamide was reported by You and co-workers [43]. This hydrogel swelled in a solution of $\mathrm{pH} 6.5$ at $25^{\circ} \mathrm{C}$ and shrunk in a solution of $\mathrm{pH} 8.5$ at $37^{\circ} \mathrm{C}$. The combined $\mathrm{pH}$ and temperature sensitivity facilitated the extended delivery of an opioid receptor antagonist, naltrexone, over a period of 28 days. Cationic graft copolymers in the form of nanoparticles based on PDMAEMA and polycaprolactone (PCL) were prepared by Gua and co-workers [44] for the encapsulation of paclitaxel and hydrophilic biomolecules. A faster release of the drug was achieved in solutions with a low $\mathrm{pH}$.

Cationic polymers have also played a role in the formulation of sustained release matrix tablets. Matrix tablets were prepared from a combination of hydrophobic ethyl cellulose and hydrophilic sodium carboxymethyl cellulose polymers. The in vitro release of losartan potassium (drug for hypertension treatment) from the matrix tablet was studied. The results showed that the formulation produced sustained drug release over a period of $12 \mathrm{~h}$. Cationic polymers in the form of biodegradable micelles have also been reported as drug carriers [45-47]. The polymer micelles were based on PDMAEMA-PCL-PDMAEMA triblocks. Successful delivery of paclitaxel into tumor cells was achieved, thus optimizing the treatment of tumor cells using cationic polymer micelles. Cationic polymers containing disulfide links prepared through a Michael addition reaction was found to conjugate doxorubicine. The polymer-drug conjugate displayed good stability in physiological $\mathrm{pH}$ conditions [48].

Amphiphilic cellulose cationic micelles were prepared by Song and co-workers [49]. This polymer self-assembled into spherical micelles in water which was used as a carrier for the lipophilic drug, prednisolone. Micelles based on PNIPAM, DMAM, and poly (lactic acid) (PLA) were prepared by Akimoto and co-workers [50]. These micelles were able to diffuse into the cells above the LCST of the polymer, due to increased interaction between the solvated micelles and cells.

ABA type triblock cationic copolymers based on PDMAEMA (block A) and PVCL (block B) were prepared by San Miguel and co-workers [51]. The formation of $\mathrm{pH}$ - and temperature-responsive micelles as well as in vitro sustained drug release were demonstrated in this study. 


\subsection{Gene Delivery Systems}

The process of administering a gene (DNA) for correcting defective genes to achieve the treatment of many genetic diseases is the principle of gene delivery/gene therapy systems. The delivery of the appropriate therapeutic gene into the cell to replace or regulate the defective gene is a vital step in gene delivery. The gene is transported in gene delivery carriers called gene carriers or vectors or vehicles. DNA is a negatively charged hydrophilic molecule that has a large size at physiological conditions and is therefore very difficult to incorporate into cells. Liposomes and polycations are two important classes of non-viral chemical gene delivery methods to condense DNA that can be transported into cell to replace the defective gene [52].

This gene delivery process using a cationic polymer or hydrogel is also called transfection. This process involves four main steps:

(1) Complexation for DNA with the cationic polymer/hydrogel. The DNA-cationic polymer/hydrogel is termed as a polyplex.

(2) Addition of the polyplex to the cell containing the defective DNA for a certain period of time.

(3) Release of DNA into the cytoplasm and removal of cationic polymer/hydrogel.

(4) Transfer of DNA into nucleus. This step involves incubation for a period of time until the desired results are obtained.

Cationic polymers can either complex with and condense DNA into small particles, or combine with DNA through conjugation, in which the covalent bond will be cleaved in order to release the DNA. To note, a major demerit of many polymer-based non-viral vectors, such as poly(ethyleneimine), PDMAEMA, and dendrimers based on poly(amido-amine), is that they show significant cytotoxicity and lower transfection efficiency [45]. Interestingly, polyplexes based on biodegradable cationic polymers show lower cytotoxicity and improved transfection efficiencies. Such polymers include poly(4-hydroxy-L-proline ester), poly[ $\alpha$-(4-aminobutyl)-L-glycolic acid] (PAGA), cationic polyphosphazenes, and linear or branched poly(amino ester)s [53-55].

Cationic polymers based on poly(amido amine)s show improved stability against hydrolysis compared to poly(amino ester)s, as the amide group is less sensitive to hydrolysis than the ester group. Ferruti and co-workers [56-60] synthesized and studied the properties and application of a wide variety of poly(amido amine)s. For these polymers, the endosomal escape of the polyplexes was attributed to the protonation of the tertiary amino groups, which induces a conformation change.

A few major barriers for non-virial gene delivery are: (i) the inefficient endosomal escape of the polyplexes to avoid the lysosome degradation pathway, and (ii) the unpacking of DNA from the polyplexes to allow transcription [61]. Lin and co-workers [62,63] reported the synthesis of novel poly(amido-amine) linear and copolymers containing disulfide linkages along the polymer backbone (Figure 4).

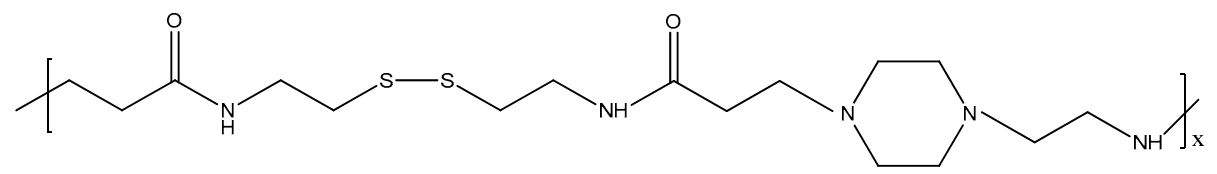

Figure 4. Chemical structure of poly(amido-amine) with disulfide linkage along the polymer backbone.

These polymers were biodegradable and showed improved biophysical properties. These polymers effectively condensed DNA into polyplexes with a size of less than $150 \mathrm{~nm}$ with a positive surface charge. These novel polymers containing disulfide linkages also facilitated polyplex unpacking, leading to enhanced gene expressions and lower levels of cytotoxicity. Hoffmann and co-workers [64] designed and functionalized a new monomer containing a disulfide linkage as a 
pendant group viz. pyridyl disulfate acrylate (PDSA). This polymer allowed efficient conjugation through disulfide linkages for effective endosomal translocation of therapeutics.

Hydrophobically modified cationic polymers with small or bulky lipids, such as cholesterol, have facilitated the translocation of DNA/s-RNA complexes through the cell membrane [65]. A biodegradable non-toxic poly[ $\alpha$-(4-aminobutyl)-L-glycolic acid] (PAGA) used as gene carrier was reported by Lim and co-workers [66]. The polymer condensed with DNA and exhibited fast degradation. The transfection efficiency of this polymer with DNA was found to be higher than the poly(L-lysine) analogues. Forrest and co-workers [67] showed that an increase in the hydrophobicity of acylated branched poly(ethylene amine) caused a fourfold uptake of polyplexes and better transfection. Among poly-L-lysine, the cholesterol-modified analogues showed improved transfection. Further, it was also shown that the incorporation of a hydrophobic cholanic acid moiety in glycol chitosan (Figure 5) was essential for the formation of polyplexes of hydrophobic p-DNA [66,67].

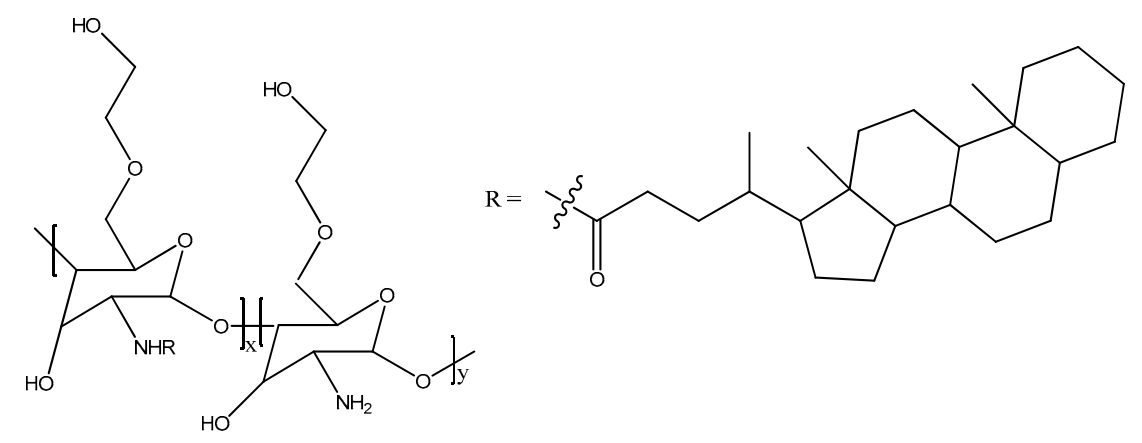

Figure 5. Chemical structure of glycol chitosan modified with cholanic acid.

\subsection{Tissue Engineering}

Natural and synthetic cationic polymers in particular porous hydrogels have been used as scaffolds to engineer various forms of new tissues. The role of most polymer scaffolds is to provide a modified surface of suitable porosity for seeded cell adhesion and interaction, very much like the extracellular matrix. The volume of tissue developed depends on the crosslinking density and the pore size of the polymer scaffolds [68]. Biocompatible and biodegradable polymers, such as cationic chitosan, poly-L-lysine, poly(ethylene imine) (PEI), etc., have been widely used for this purpose. Various PEI polymers $[69,70]$ have been used to fabricate scaffolds for cultivating bovine chondrocytes and normal human fibroblast cells.

The porous scaffolds of chitosan reinforced with calcium phosphate for improved osteo-retention have been used in bone tissue engineering. This reinforced cationic polymer scaffold was used to regenerate new bone tissue of increased fracture and fatigue resistance [71]. Fiber mesh scaffolds and microspheres based on chitosan have also been studied for bone generation, cell adhesion, and viability [72]. Using chitosan and chitin scaffolds grafted with poly(L-lysine) (PLL), the efficient generation of cartilaginous components was achieved, thus showing the potential application of cationic polymers in articular cartilage engineering.

\subsection{Nanoparticles and Microparticles Based on Cationic Polymers}

Polymeric nanoparticles and microparticles are of special interest because of their properties such as nontoxicity, biocompatibilty, and stimuli-sensitivity. Nano/microparticles based on cationic polymers may enhance the cellular uptake and endosomal escape of the particles [73]. These materials have been synthesized by methods such as solvent evaporation [74], spray drying [75], emulsification [76], ionotropic gelation [77], and controlled polymerization methods such as atom transfer radical polymerization (ATRP) [78]. Nano or microshperes of chitosan have been widely used for the delivery of insulin [79], heparin [80], cyclosporin A [81], and a variety of proteins [82]. 
An important application of cationic polymers in the form of nanoparticles is in the deliverly of hydrophobic drugs. Almost one-thrid of newly deiscovered drug molecules are sparingly soluble in water [83]. Cationic copolymers based on 5-Z-amino- $\delta$-valerolactone and $\varepsilon$-caprolactone assemble into nanoaggregates at concentrations above $0.5 \mathrm{mg} \mathrm{mL}^{-1}$, thereby increasing the water solubility of hydrophobic drugs by about 100-1000 times [84].

\subsection{Multilayer Films or Coatings}

Multilayer films of polymers are usually obained by the layer-by-layer method, usually from oppositely charged polyelectrolytes, neutral polymers, cationic dendrimers [85], or polycations. The films may be deposited onto nano/microspheres, forming the desired capsules for drug encapsulation [86]. A schematic represenation of the various methods used to obtain coated multilayer films for drug delivery is shown in Figure 6. The drug can also be introduced into the nano/microshperes before coating them with multilayer film, or the core of the capsule can be selectively removed before encapsulating the drug. In this case, the capsules serve as sacrifical templates [87].

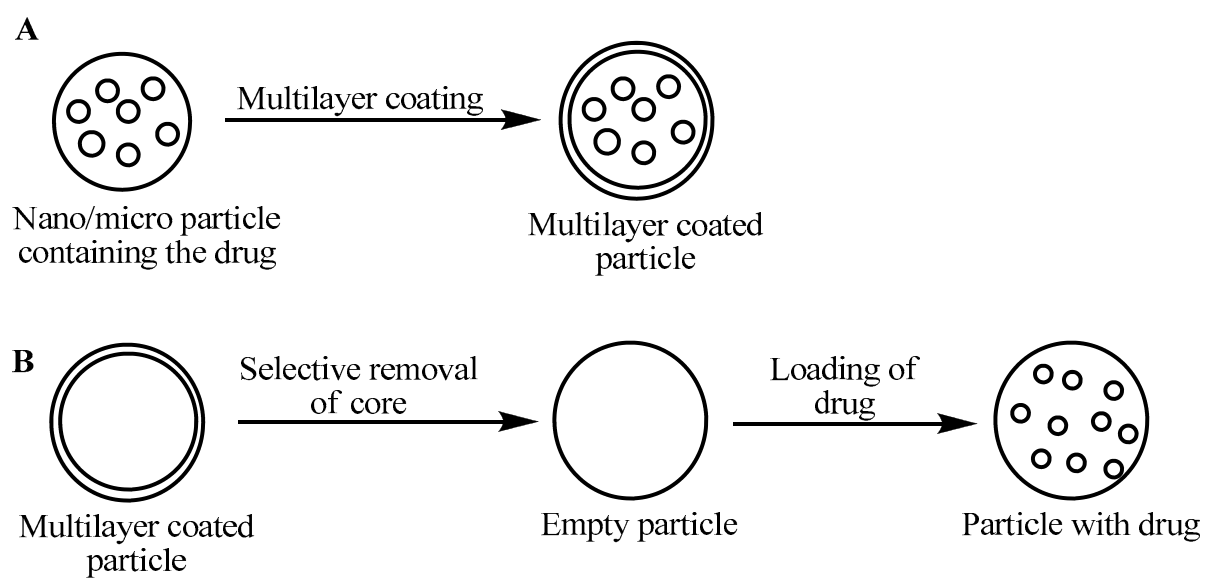

Figure 6. Methods to obtain multilayer polymer films of drug delivery systems. (A) Multilayer coating on particle with encapsualted drug; (B) sacrificial removal of core followed by drug loading.

The main disadvantage of hollow capsules is the low efficiency of drug loading due to the adsorption of the drug on the walls of the capsule rather than in the core. Various cationic polymers, such as chitosan, protamine, poly(4-vinyl pyridine), poly(diallyl dimethylammonium chloride), poly(L-arginine), poly(dimethyl aminoethyl methacrylate) [88-91], etc., have been used in the preparation of multilayer films. The number of layers or thickness of the capsules is related to the permeability and the release of the active substances. It has been found that the permeability decreases with an increase in the thickness of the layers [91]. The rate of release of a drug can be greatly controlled by coating the drug directly with a multilayer film. The release rate of furosemide microcrystals coated with cationic polymers with a thickness of $150 \mathrm{~nm}$ was found to reduce the rate up to 300 times compared to the uncoated drug [92].

\section{Conclusions}

In summary, stimuli-responsive cationic polymers show interesting properties in response to changes in the external $\mathrm{pH}$ of the medium. In this paper, a brief introduction to cationic polymers/hydrogels in terms of design, theory of swelling, and recent biomedical applications such as drug and gene delivery and tissue engineering has been compiled. Based on the variety of cationic polymers and their interesting properties, these materials show promise and will have a definite impact on the formation of polymer-based biomaterials and chemical sensors. 
Author Contributions: G. Roshan Deen and Xian Jun Loh jointly wrote the paper.

Conflicts of Interest: The authors declare no conflict of interest.

\section{References}

1. Roshan Deen, G.; Mah, C.H. Influence of external stimuli on the network properties of cationic poly(N-acryloyl-N'-propyl piperazine) hydrogels. Polymer 2016, 89, 55-68. [CrossRef]

2. Tang, S.; Floy, M.; Bhandari, R.; Dziubla, T.; Zach Hilt, J. Development of novel $N$-isopropylacrylamide (NIPAAm) based hydrogels with varying content of chrysin multiacrylate. Gels 2017, 3, 40. [CrossRef]

3. Stayton, P.S.; Shimoboji, T.; Long, C. Control of protein-ligand recognition using a stimuli-responsive polymer. Nature 1995, 378, 472-474. [CrossRef] [PubMed]

4. Jeong, B.; Bae, Y.H.; Kim, S.W. Biodegradable block copolymers as injectable drug delivery systems. Nature 1997, 388, 860-862. [CrossRef] [PubMed]

5. Hatefi, A.; Amsden, B. Biodegradable injectable in-situ forming drug delivery systems. J. Control Release 2002, 80, 9-28. [CrossRef]

6. Pasparakis, G.; Vamvakaki, M. Multiresponsive polymers: Nano-sized assemblies, stimuli-sensitive gels and smart surfaces. Polym. Chem. 2011, 2, 1234-1248. [CrossRef]

7. Ahn, S.; Kasi, R.M.; Kim, S.; Sharma, N.; Zhou, Y. Stimuli-responsive polymer gels. Soft Matter 2008, 4, 1151-1157. [CrossRef]

8. Almdal, K.; Dyre, J.; Hvidt, S.; Kramer, O. Towards a phenomenological definition of the term 'gel'. Polym. Gels Netw. 1993, 1,5-17. [CrossRef]

9. Tanaka, T. Collapse of Gels and the Critical Endpoint. Phys. Rev. Lett. 1978, 40, 820-823. [CrossRef]

10. Vihola, H.; Laukkanen, A.; Tenhu, H.; Hirvonen, J. Drug release chracteristics of physically cross-linked thermosensitive poly( $N$-vinylcaprolactam) hydrogel particles. J. Pharm. Sci. 2008, 97, 4783-4793. [CrossRef] [PubMed]

11. Qiu, Y.; Park, K. Environment-sensitive hydrogels for drug delivery. Adv. Drug Del. Rev. 2001, 53, $321-339$. [CrossRef]

12. Gil, E.S.; Hudosn, S.M. Stimuli-responsive polymers and their bioconjugates. Prog. Polym. Sci. 2004, 29, 1173-1222. [CrossRef]

13. Aguilar, M.R.; Elvira, C.; Gallardo, A.; Vázquez, B.; Román, J.S. Smart polymers and their applications as biomaterials. Top. Tissue Eng. 2007, 3, 1-27.

14. Katchalsky, A. Rapid swelling and deswelling of reversible gels of polymeric acids by ionization. Cell. Mol. Life Sci. 1949, 5, 319-320. [CrossRef]

15. Tanaka, T. Phase transition in gels and a single polymer. Polymer 1979, 20, 1404-1412. [CrossRef]

16. Firestone, B.A.; Siegel, R.A. Dynamic pH-dependent swelling of a hydrophobic polyelectrolyte gel. Polym. Commun. 1988, 29, 204-208.

17. Peppas, N.A.; Bures, P.; Leobandung, W.; Ichikawa, H. Hydrogels in pharmaceutical formulations. Eur. J. Pharm. Biopharm. 2000, 50, 27-46. [CrossRef]

18. Ferruti, P.; Marchisio, M.A.; Duncan, R. Poly(amido-amine)S: Biomedical applications. Macromol. Rapid Commun. 2002, 23, 332-355. [CrossRef]

19. Gan, L.H.; Gan, Y.Y.; Roshan Deen, G. Poly(N-acryloyl- $N^{\prime}$-propyl piperazine): A new stimuli-responsive polymer. Macromolecules 2000, 33, 7893-7897. [CrossRef]

20. Bulmus, V.; Ding, Z.; Long, C.J.; Stayton, P.S.; Hoffman, A.S. Site-specific polymer-streptavidin bioconjugate for $\mathrm{pH}$-controlled binding and triggered release of biotin. Bioconjug. Chem. 2000, 11, 78-83. [CrossRef] [PubMed]

21. Brazel, C.S.; Peppas, N.A. Synthesis and Characterization of thermo- and chemomechanically responsive poly(isopropylacrylamide-co-methacrylic acid) hydrogels. Macromolecules 1995, 28, 8016-8020. [CrossRef]

22. Roshan Deen, G.; Gan, L.H. Determination of reactivity ratios and swelling characteristics of stimuli-responsive copolymers of $N$-acryloyl- $N^{\prime}$-ethyl piperazine and MMA. Polymer 2006, 47, 5025-5034. [CrossRef]

23. Roshan Deen, G.; Chua, V.; Ilyas, U. Synthesis, swelling properties and network structure of new stimuli-responsive poly( $N$-acryloyl- $N^{\prime}$-ethyl piperazine-co- $N$-isopropylacrylamide) hydrogels. J. Polym. Sci. Polym. Chem. 2012, 50, 3363-3372. [CrossRef] 
24. Roshan Deen, G.; Lim, E.K.; Mah, C.H.; Heng, K.M. New cationic linear copolymers and hydrogels of $\mathrm{N}$-vinyl caprolactam and $N$-acryloyl- $N^{\prime}$-ethyl piperazine: Synthesis, reactivity, influence of external stimuli on the LCST and swelling properties. Ind. Eng. Chem. Res. 2012, 51, 13354-13365. [CrossRef]

25. Gan, L.H.; Roshan Deen, G.; Loh, X.J.; Gan, Y.Y. New stimuli-responsive copolymers of $N$-acryloyl- $N^{\prime}$-alkyl piperazine and methyl methacrylate. Polymer 2001, 42, 65-69. [CrossRef]

26. Roshan Deen, G.; Lee, T.T. New pH-responsive linear and crosslinked functional copolymers of $N$-acryloyl- $N^{\prime}$-phenyl piperazine with acrylic acid and hydroxyethyl methcrylate: Synthesis, reactivity, and effect of steric hindrance on swelling. Polym. Bull. 2012, 69, 827-846. [CrossRef]

27. Verestiuc, L.; Ivanov, C.; Barbu, E.; Tsibouklis, J. Dual-stimuli-responsive hydrogels based on poly(N-isopropylacrylamide)/chitosan semi-interpenetrating networks. Int. J. Pharm. 2004, 269, 185-194. [CrossRef] [PubMed]

28. Gonzalez, N.; Elvira, C.; Roman, S.J. Novel dual-stimuli-responsive polymers derived from ethylpyrrolidine. Macromolecules 2005, 38, 9298-9303. [CrossRef]

29. Kurata, K.; Dobashi, A. Novel temperature and pH-responsive linear polymers and crosslinked hydrogels comprised of acidic L- $\alpha$-amino acid derivatives. J. Macromol. Sci. Part A Pure Appl. Chem. 2004, 41, 143-164. [CrossRef]

30. Roshan Deen, G.; Gan, Y.Y.; Gan, L.H.; Teng, S.H. New functional copolymers of N-acryloyl- $N^{\prime}$-methyl piperazine and 2-hydroxyethyl methacrylate: Synthesis, determination of reactivity ratios and swelling characteristics of gels. Polym. Bull. 2011, 66, 301-313. [CrossRef]

31. Velasco, D.; Elvira, C.; Román, J.S. New stimuli-responsive polymers derived from morpholine and pyrrolidine. J. Mater. Sci. Mater. Med. 2008, 19, 1453-1458. [CrossRef] [PubMed]

32. Oupicky, D.; Parker, A.L.; Seymour, L.W. Laterally stabilized complexes of DNA with linear reducible polycations: Strategy for triggered inracellular activation of DNA delivery vectors. J. Am. Chem. Soc. 2002, 124, 8-9. [CrossRef] [PubMed]

33. Lim, Y.B.; Kim, S.M.; Lee, Y.; Lee, W.K.; Yang, T.G.; Lee, M.J.; Suh, H.; Park, J.S. Cationic hyperbranched poly(amino ester): A novel class of DNA condensing molecule with cationic surface, biodegradable three-dimensional structure, and tertiary amine group in the interior. J. Am. Chem. Soc. 2001, 123, 2460-2461. [CrossRef] [PubMed]

34. Matsuo, E.S.; Tanaka, T. Kinetic of discontinuous volume-phase transition of gels. J. Chem. Phys. 1988, 89, 1695-1703. [CrossRef]

35. Dušek, K.; Patterson, D. Transition in swollen polymer network induced by intermolecular condensation. J. Polym. Sci. Part A-2 1986, 6, 1209-1216. [CrossRef]

36. Flory, P.J. Phase equilibria in polymer systems: Swelling of network structures. In Principles of Polymer Chemistry; Cornell University: Ithaca, NY, USA, 1953.

37. Flory, P.J.; Rehner, J. Statistical mechanics of cross-linked polymer networks II. Swelling. J. Chem. Phys. 1943, 11, 521-546. [CrossRef]

38. Ricka, J.; Tanaka, T. Swelling of ionic gels: Quantitative performance of the Donnan theory. Macromolecules 1984, 17, 2916-2921. [CrossRef]

39. Vasheghani-Farahani, E.; Vera, J.H.; Cooper, D.G.; Weber, M.E. Swelling of ionic gels in electrolyte solutions. Ind. Eng. Chem. Res. 1990, 29, 554-560. [CrossRef]

40. Patil, V.R.; AMiji, M.M. Preparation and characterization of freeze-dried chitosan-poly(ethylene oxide) hydrogels for site-specific antibiotic delivery in the stomach. Pharm. Res. 1996, 13, 588-593. [CrossRef]

41. Gallardo, A.; Rodriguez, G.; Aguilar, M.R.; Fernandez, M.M.; Román, S.J. A kinetic model to explain the zero-order release of drugs from ionic polymer drug conjugates: Application to AMPS-Triflusal-derived polymeric drugs. Macromolecules 2003, 36, 8876-8880. [CrossRef]

42. Kamada, H.; Tsutsumi, Y.; Yoshioka, Y. Design of a pH-Sensitive Polymeric Carrier for Drug Release and its Application in Cancer Therapy. Clin. Cancer Res. 2004, 10, 2545-2550. [CrossRef] [PubMed]

43. You, J.; Almeda, D.; Ye, G.J.C.; Auguste, D.T. Bioresponsive matrices in drug delivery. J. Biol. Eng. 2010, 4, 1-12. [CrossRef] [PubMed]

44. Gua, S.; Qiao, Y.; Wang, W.; He, H.; Deng, L.; Xing, J.; Xu, J.; Liang, X.J.; Dong, A. Poly( $\varepsilon$-caprolactone)-graft-poly(2-N,N-dimethylamino) ethyl methacrylate) nanoparticles: $\mathrm{PH}$ dependent thermo-sensitive multifunctional carriers for gene and drug delivery. J. Mater. Chem. 2010, 20, 6935-6941. [CrossRef] 
45. Zhu, C.; Jung, S.; Luo, S.; Meng, F.; Zhu, X.; Park, T.G.; Zhong, Z. Co-delivery of siRNA and paclitaxel into cancer cells by biodegradable cationic micelles based on PDMAEMA-PCL-PDMAEMA triblock copolymers. Biomaterials 2010, 31, 2408-2416. [CrossRef] [PubMed]

46. Huang, X.N.; Du, F.S.; Cheng, J.; Dong, Y.Q.; Liang, D.H.; Ji, S.P.; Lin, S.S.; Li, Z.C. Acid-sensitive polymeric micelles based on thermoresponsive block copolymers with pendent cyclic orthoester groups. Macromolecules 2009, 42, 783-790. [CrossRef]

47. Hruby, M.; Filippov, S.K.; Panke, J.; Novakova, M.; Mackova, H.; Kucka, J.; Vetvicka, D.; Ulbrich, K. Polyoxazoline thermoresponsive micelles as radionuclide delivery systems. Macromol. Biosci. 2010, 10, 916-924. [CrossRef] [PubMed]

48. Lagvinac, N.; Nichols, J.L.; Ferruti, P.; Duncan, R. Poly(amidoamine) Conjugates Containing Doxorubicin Bound via an Acid-Sensitive Linker. Macromol. Biosci. 2009, 9, 480-487.

49. Song, Y.; Zhong, L.; Gan, W.; Zhou, J.; Zhang, L. Self-assembled micelles based on hydrophobically modified quaternized cellulose for drug delivery. Colloids Surf. B 2011, 83, 313-320. [CrossRef] [PubMed]

50. Akimoto, J.; Nakayama, M.; Sakai, K.; Okano, T. Temperature-induced intracellular uptake of thermoresponsive polymeric micelles. Biomacromolecules 2009, 10, 1331-1336. [CrossRef] [PubMed]

51. San Miguel, V.; Limer, A.J.; Haddleton, D.M.; Catalina, F.; Peinado, C. Biodegradable and thermoresponsive micelles of triblock copolymers based on 2-( $N, N$-dimethylamino)ethyl methacrylate and epsilon-caprolactam for controlled drug delivery. Eur. Polym. J. 2008, 44, 3853-3863. [CrossRef]

52. Godbey, W.T.; Mikos, A.G. Recent progress in gene delivery using non-virial transfer complexes. J. Control Release 2001, 72, 115-125. [CrossRef]

53. Lim, Y.B.; Choi, Y.H.; Park, J.S. A self-destroying polycationic polymer: Biodegradable poly(4-hydroxylL-proline ester). J. Am. Chem. Soc. 1999, 121, 5633-5639. [CrossRef]

54. Putnam, D.; Langer, R. Poly(4-hydroxyl-L-proline ester): Low temperature polycondensation and plasmid DNA complexation. Macromolecules 1999, 32, 3658-3662. [CrossRef]

55. Lim, Y.B.; Kim, C.H.; Kim, K.; Kim, S.W.; Park, J.S. Development of a safe gene delivery system using biodegrdable polymer, poly[ $\alpha$-(4-aminobutyl)-L-glycolic acid]. J. Am. Chem. Soc. 2000, 122, 6524-6525. [CrossRef]

56. Lynn, D.M.; Langer, R. Degradable poly( $\beta$-amino esters): Synthesis, characterization, and self-assembly with plasmid DNA. J. Am. Chem. Soc. 2000, 122, 10761-10768. [CrossRef]

57. Emilitri, E.; Ranucci, E.; Ferruti, P. New poly(amidoamine)s containing disulfide linkages in their main chain. J. Polym. Sci. Polym. Chem. 2005, 43, 1404-1416. [CrossRef]

58. Richardson, S.C.W.; Pattrick, N.G.; Man, Y.K.S.; Ferruti, P.; Duncan, R. Poly(amido-amine)s as potential nonviral vectors: Ability to form interpolyelectrolyte complexes and to mediate transfection in vitro. Biomacromolecules 2001, 2, 1023-1028. [CrossRef] [PubMed]

59. Ferruti, P.; Manzoni, S.; Richardson, S.C.W.; Duncan, R.; Pattrick, N.G.; Mendichi, R.; Casolaro, M. Amphoteric linear poly(amio-amine)s as endosomolytic polymers: Correlation between physicochemical and biological properties. Macromolecules 2000, 33, 7793-7800. [CrossRef]

60. Ferruti, P.; Knobloch, S.; Ranucci, E.; Duncan, R.; Gianasi, E. A Novel Modification of poly(L-lysine) leading to a soluble cationic polymer with reduced toxicity and with potential as a transfection agent. Macromol. Chem. Phys. 1998, 199, 2565-2575. [CrossRef]

61. Boussif, O.; Lezoulach, F.; Zanta, M.A.; Mergny, M.D.; Scherman, D.; Demeneix, B.; Behr, J.P. A versatile vector for gene and oligonucleotide transfer into cells in culture and in vivo: Polyethylenimine. Proc. Natl. Acad. Sci. USA 1995, 92, 7297-7301. [CrossRef] [PubMed]

62. Lin, C.; Zhong, Z.; Lok, M.C.; Jiang, X.; Hennink, W.E.; Feijen, J.; Engbersen, J.F.J. Linear poly(amido amine)s with secondary and tertiary amino groups and variable amounts of disulfide linkages: Synthesis and in vitro gene transfer properties. J. Control. Rel. 2006, 116, 130-137. [CrossRef] [PubMed]

63. Jiang, X.L.; van der Horst, A.; van Steenbergen, M.J.; Akeroyd, N.; van Nostrum, C.F.; Schoenmakers, P.J.; Hennink, W.E. Molar-mass characterization of cationic polymers for gene delivery by aqueous size-exclusion chromatrography. Pharm. Res. 2006, 23, 595-603. [CrossRef] [PubMed]

64. Stayton, P.S.; Hoffman, A.S.; Murthy, N. Molecular engineering of proteins and polymers for targeting and intracellular delivery of therapeutics. J. Control. Release 2000, 65, 203-220. [CrossRef]

65. Vanessa, I.; Afsaneh, L.; Hasana, U. Lipid and Hydrophobic Modification of Cationic Carriers on Route to Superior Gene Vectors. Soft Matter 2010, 6, 2124-2138. 
66. Lim, Y.B.; Han, S.-A.; Kong, H.-U.; Park, J.-S.; Jeong, B.; Kim, S.W. Biodegradable polyester, Poly[ $\alpha$-(4-Aminobutyl)-I-Glycolic Acid]], as a Non-Toxic Gene Carrier. Pharm. Res. 2000, 17, 811-816. [CrossRef] [PubMed]

67. Forrest, M.L.; Meister, G.E.; Koerber, J.T.; Pack, D.W. Partial Acetylation of Polyethylenimine Enhances in vitro Gene Delivery. Pharm. Res. 2004, 21, 365-371. [CrossRef] [PubMed]

68. Lee, K.Y.; David, J.M. Hydrogels for Tissue Engineering. Chem. Rev. 2001, 101, 1869-1880. [CrossRef] [PubMed]

69. Sangram, K.S.; Mamoni, D.; Sandra, V.V.; David, L.K.; Emo, C.; Clemens, V.B.; Lorenzo, M.; Peter, D. Cationic Polymers and their Therapeutic Potential. Chem. Soc. Rev. 2012, 41, 7147-7194.

70. Kuo, Y.C.; Ku, N. Appplication of Polyethyleneimine-modified Scaffolds to the regeneration of Cartilaginous Tissue. Biotechnol. Prog. 2009, 25, 1459-1467. [CrossRef] [PubMed]

71. Zhao, L.; Burguera, E.F.; Xu, H.H.K.; Amin, N.; Ryon, H.; Arola, D.D. Fatigue and Human Umbilical Cord Stem Cell Seeding Characteristics of Calcium Phosphate-chitosan-biodegradable Fiber Scaffolds. Biomaterials 2010, 31, 840-847. [CrossRef] [PubMed]

72. Tuzlakoglu, K.; Alves, C.M.; Mano, J.F.; Reis, R.L. Production and Characterization of Chitosan Fibers and 3-D Fiber Mesh Scaffolds for Tissue Engineering Applications. Macromol. Biosci. 2004, 4, 811-819. [CrossRef] [PubMed]

73. Elsabahy, M.; Wooley, K.L. Design of Polymeric Nanoparticles for Biomedical Delivery. Chem. Soc. Rev. 2012, 41, 2545-2561. [CrossRef] [PubMed]

74. Hoffart, V.; Lamprecht, A.; Maincent, P.; Lecompte, T.; Vigneron, C.; Ubrich, N. Oral bioavailability of a Low Molecular Weight Heparin using a Polymeric Delivery system. J. Control. Release 2006, 113, 38-42. [PubMed]

75. Zhang, S.; Uludağ, H. Nanoparticle Systems for Growth Factor Delivery. Pharm. Res. 2009, 26, 1561-1580. [CrossRef] [PubMed]

76. Hoffart, V.; Ubrich, N.; Lamprecht, A.; Bachelier, K.; Vigneron, C.; Lecompte, T.; Hoffman, M.; Maincent, P. Microencapsulation of Low Molecular weight Heparin into polymeric Particles Designed with Biodegradabel and Nonbiodegradable Polycationic Polymers. Drug Deliv. 2003, 10, 1-7. [CrossRef] [PubMed]

77. Hamidi, M.; Azadi, A.; Mohamdi-Samani, S.; Rafiei, P.; Ashrafi, H. A Pharmokinetic Overveiw of Nanotechnology based Drug Delivery System. J. Appl. Polym. Sci. 2012, 124, 4686-4693.

78. Simakova, A.; Averick, S.E.; Konkolewicz, D.; Matyjaszewski, K. Aqueous ARGET ATRP. Macromolecules 2012, 45, 6371-6379. [CrossRef]

79. Mahkam, M. Modified Chitosan Crosslinked Starch Polymers for Oral Insulin Delivery. J. Bioact. Compat. Polym. 2010, 25, 406-411. [CrossRef]

80. Shao, Y.; Zhu, B.; Li, J.; Liu, X.; Tan, X.; Yang, X. Novel Chitosan Microshphere-Templated Microcapsules. Mater. Sci. Eng. C 2009, 29, 936-942. [CrossRef]

81. El-Shabouri, M.H. Positively Charged Nanoparticles for Improving the Oral Bioavailability of Cyclosporin-A. Int. J. Pharm. 2002, 249, 101-108. [CrossRef]

82. Zubareva, A.; Ilyina, A.; Prokhorov, A.; Kurek, D.; Efremov, M.; Varlamov, V.; Senel, S.; Ignatyev, P.; Svirshchevskaya, E. Characterization of Protein and Peptide Binding to Nanogels Form3ed by Differently Charged Chitosan Derivatives. Molecules 2013, 18, 7848-7864. [CrossRef] [PubMed]

83. Lipinski, C.A. Drug-like Properties and the Causes of Poor Solubility and Poor Permeability. J. Pharmacol. Toxicol. Methods 2000, 44, 235-249. [CrossRef]

84. Nottelet, B.; Patterer, M.; Francois, B.; Schott, M.; Domurado, M.; Garric, X.; Domurado, D.; Coudane, J. Nanoaggregates of Biodegradable Amphiphilic Randon Polycations for delivering Water-insoluble Drugs. Biomacromolecules 2012, 13, 1544-1553. [CrossRef] [PubMed]

85. Khopade, A.J.; Caruso, F. Electrostatically Assembled Polyelectrolyte/Dendrimer Multilayer Films as Ultrathin Nanoreservoirs. Nano Lett. 2002, 2, 415-441. [CrossRef]

86. Tong, W.; Song, X.; Gao, C. Layer-by-Layer Assembly of Micorcapsules and their Biomedical Applications. Chem. Soc. Rev. 2012, 41, 6103-6124. [CrossRef] [PubMed]

87. Gao, C.; Donath, E.; Mohwald, H.; Shen, J. Spontaneous Deposition of Water-Soluble Substances into Microcapsules: Phenomenon, Mechanism, and Application. Angew. Chem. Int. Ed. 2002, 41, 3789-3793. [CrossRef]

88. Ye, S.; Wang, C.; Liu, X.; Tong, Z. Chitosan in Nanostructured Thin Films. J. Control. Release 2005, 106, 319-328. [CrossRef] [PubMed] 
89. Qiu, X.; Donath, E.; Mohwald, H. Permeability of Ibuprofen in Various Polyelectrolyte Multilayers. Macromol. Mater. Eng. 2001, 286, 591-597. [CrossRef]

90. Ai, H.; Fang, M.; Jones, S.A.; Lvov, Y.M. Electrostatic Layer-by-Layer Nanoassembly on Biological Microtemplates: Platelets. Biomacromolecules 2002, 3, 560-564. [CrossRef] [PubMed]

91. Borodina, T.; Markvicheva, E.; Kunizhev, S.; Mohawld, H.; Sukhorukov, G.B.; Kreft, O. Controlled Release of DNA from Self-degrading Microcapsules. Macromol. Rapid Commun. 2007, 28, 1894-1899. [CrossRef]

92. Ai, H.; Jones, S.A.; De Villiers, M.M.; Lvov, Y.M. Nano-encapsulation of Furosemide Microcrystals for Controlled Drug Release. J. Control. Release 2003, 86, 59-68. [CrossRef]

(C) 2018 by the authors. Licensee MDPI, Basel, Switzerland. This article is an open access article distributed under the terms and conditions of the Creative Commons Attribution (CC BY) license (http://creativecommons.org/licenses/by/4.0/). 